International Journal of Economics, Business and Accounting Research (IJEBAR)

Peer Reviewed - International Journal

Vol-5, Issue-1, 2021 (IJEBAR)

E-ISSN: 2614-1280 P-ISSN 2622-4771

https://jurnal.stie-aas.ac.id/index.php/IJEBAR

\title{
INTERNAL CONTROL SYSTEM, UTILIZATION OF ACCOUNTING INFORMATION TECHNOLOGY, ON VILLAGE FUND MANAGEMENT ACCOUNTABILITY
}

\author{
Yenty Astari Dewi, ${ }^{1)}$ Nasfi, ${ }^{2)}$ Mai Yuliza ${ }^{3)^{*}}$ \\ ${ }^{1}$ Sharia Banking Study Program, IAIN, Bukittinggi \\ ${ }^{2}$ Sharia Banking Study Program, STES Manna Wa Salwa, Padang Panjang \\ ${ }^{3 *}$ Program of Management Studies, STIE Pasaman \\ ${ }^{1}$ E-mail: yentyastariedewi@gmail.com \\ ${ }^{2}$ E-mail: nasfi.anwar@gmail.com \\ 3* Corresponding E-mail: mai.yuliza@gmail.com
}

\begin{abstract}
The government prioritizes Villages in development, providing funds for Villages which are taken directly from the State Revenue and Expenditure Budget to be managed by the Village independently. The research objective was to determine the effect of the influence of the internal control system, the use of accounting information technology, and the competence of the Nagari apparatus on the accountability of village fund management. This type of quantitative research, a sample of 20 Nagari in Agam District, as many as 80 respondents, using convenience sampling techniques, the data in this study were collected using a questionnaire and analyzed using multiple regression analysis. The results of the research $F$ test results $F$ value 31.750> $F$ table 2.74, 95\% confidence level and significant 0.05 , Fcount $>F$ table conclusion that there is an effect of independent variables $\left(X_{1}, X_{2}\right.$ and $\left.X_{3}\right)$ on the dependent variable $(Y)$ simultaneously. A separate t-test test found that the internal control system variable $\left(X_{1}\right)$ did not have a significant effect on the accountability of Village Fund management, the variable use of accounting information technology and the competence of Nagari officials $\left(X_{2}\right.$ and $\left.X_{3}\right)$ had a significant effect on the accountability of Village Fund management.
\end{abstract}

Keywords: Internal Control System, Utilization of Accounting Information Technology, Nagari Apparatus Competence, Accountability, Village Fund.

\section{Introduction}

Villages have a strategic role to assist regional governments in the process of administering governance. This is a concrete step for the regional government to support the implementation of regional autonomy in their region. Based on Law no. 6 of 2014 concerning Village, the village has to regulate and manage the local community according to social and cultural conditions, including in financial arrangements (Sabri et al., 2019).

The village law has designated the village as the spearhead of development and improvement of the economy and community welfare in order to alleviate poverty (Nasfi, 2020). In Islam it is recommended that every ummah should carry out development, economy and empowerment accordingly Al-Quran letter $A l-R a$ 'du paragraph 11.

Letter Al-Ra'du paragraph 11 This provides an explanation that there is an opportunity for Muslims to empower themselves or their people through hard work, which is supported by the government through one of the Village fund programs, to maximize development and the 
International Journal of Economics, Business and Accounting Research (IJEBAR)

Peer Reviewed - International Journal

Vol-5, Issue-1, 2021 (IJEBAR)

E-ISSN: 2614-1280 P-ISSN 2622-4771

https://jurnal.stie-aas.ac.id/index.php/IJEBAR

economy as well as the welfare of the Village community which is budgeted from APBN funds (Indrawati, 2017).

The use of the Village Fund allocation has resulted in facilities / infrastructure that are beneficial to the community, including, in the form of construction of Village roads, Village bridges, clean water connections for the Village, boat moorings, PAUD, Polindes, Village wells, drainage, irrigation, posyandu, and Village markets. The goal is to improve the quality of life of the village community and reduce the percentage of poor people (Indrawati, 2017), where the amount of the fund is 2015-2019, according to the Ministry of Finance's data as follows :

Table 1. Allocation of village funds 2015-2019

(Billions of Rupiah)

\begin{tabular}{|c|c|c|c|}
\hline Year & National & $\begin{array}{c}\text { Province } \\
\text { West Sumatra }\end{array}$ & $\begin{array}{c}\text { Agam } \\
\text { Regency }\end{array}$ \\
\hline 2015 & 20.700 & 267 & 25 \\
\hline 2016 & 46.980 & 599 & 56 \\
\hline 2017 & 60.000 & 797 & 71 \\
\hline 2018 & 60.000 & 791 & 64 \\
\hline 2019 & 70.000 & 932 & 74 \\
\hline
\end{tabular}

Source : Data www.djpk.kemenkeu.go.id

There are various problems in the management of Village Funds in the management of Village Funds, namely, seen from the distribution point of view, one of the obstacles to the Village Fund is that the previous stage of the distribution and use of the Village Fund was not submitted so that the next stage of the funds could not be distributed anymore (Ismail, Widagdo and Widodo, 2016). Apart from disbursing the constraints faced in the use of Village Funds, namely, the use of Village Funds outside the priority areas, the disbursement of Village Funds is not supported by adequate evidence, The village does not yet recognize the supply money mechanism so that the funds that have been distributed to the Village RK are withdrawn and stored outside the village RK, and expenditures outside those that have been budgeted by the Village Budget (Rustiarini and Denpasar, 2016).

Agam District received the Village / Nagari Fund Allocation, in which the Village Fund allocation was submitted and managed by Nagari from 2015-2019 as follows;

Table 2. Average Village Fund Allocation in each Nagari in Agam District 2015-2019

\begin{tabular}{|c|c|}
\hline Year & Total \\
\hline 2015 & Rp.280.000.000 \\
\hline 2016 & Rp.628.000.000 \\
\hline 2017 & Rp.800.000.000 \\
\hline 2018 & Rp.780.000.000 \\
\hline 2019 & Rp .933.900.000 \\
\hline
\end{tabular}

Source: Data www.djpk.kemenkeu.go.id

Where the problems that arise in the management of the Village Fund in Agam Regency are not realized Rp. 3.56 Billion (2018) from the budget and incomplete programs (Febriyanti and 
International Journal of Economics, Business and Accounting Research (IJEBAR)

Peer Reviewed - International Journal

Vol-5, Issue-1, 2021 (IJEBAR)

E-ISSN: 2614-1280 P-ISSN 2622-4771

https://jurnal.stie-aas.ac.id/index.php/IJEBAR

Halmawati, 2020). Based on the principles in village financial management with Permendagri Number 113 of 2014 concerning village financial management, namely accountability, then in the management of Village Fund allocations requires accountability, namely the process of managing the Village Fund allocation starting from planning, implementation, reporting, accountability that can truly be accountable to the community. Accountability becomes an apparatus full control over everything that has been done in a government, so that the role of the government as an agent becomes an important factor in being accountable for the performance of the government to the principals or the people (Widyatama, Novita and Diarespati, 2017).

Financial reporting in the management of the Village Fund refers to PSAP No. 01 concerning Presentation of Financial Statements, where the purpose of financial statements is to present information that is useful for decision making and to demonstrate the accountability of the reporting entity for the resources entrusted by Nagari / Village (Herdiyana, 2019). Therefore, in the management of Village Funds, accounting information technology is needed to achieve accountability for Village Fund Management in accordance with Government Regulation No.56 of 2005 concerning Regional Financial Information Systems where central and regional governments are required to use information technology in order to improve the ability to manage regional finances and distribute regional financial information to public services (Pahlawan, Wijayanti and Suhendro, 2020). Responding to this in the management of the Village Fund, the Government has implemented accounting information technology, namely the application of accounting applications in the Nagari/Village Government in the form of SISKEUDES (Sistem Keuangan Desa) (Sari, 2017).

Research and discussion are limited to the Influence of Internal Control Systems, Utilization of Accounting Information Technology, and Nagari/Village Apparatus Competence on Accountability of Village Fund Management Case Studies on Nagari/Village Government in Agam. The research objective is to see the influence of the internal control system on the accountability of village / nagari fund management and the influence of the use of accounting information technology on the accountability of village fund management and to determine the effect of the competence of the Nagari apparatus on the accountability of village fund management in village / nagari governance in Agam Regency. The benefits of research are useful for the academic world as a reference for students and teaching staff and the Nagari / Village government in Agam Regency as input and consideration for accountability in managing village funds as well as for other parties who need reading and research references.

\section{Literature Review}

Accounting is the activity of collecting, analyzing, presenting in numerical form, classifying, recording, summarizing, and reporting the transaction activities of an organization in the form of financial information (Rudianto, 2010). According to Government Accounting Standards, Accounting is the process of recording, measuring, classifying, summarizing, transactions and financial events, interpreting the results and presenting financial statements (Hamzah, 2016).

In Musyidi (2009) government accounting, many states the old terminology and shift to public sector accounting terms. Public sector accounting is an accounting system used by public institutions as a means of accountability to the public (Lumempow, Elim and Suwetja, 2017). Accounting practices carried out by public institutions, both government sector accounting and 
International Journal of Economics, Business and Accounting Research (IJEBAR)

Peer Reviewed - International Journal

Vol-5, Issue-1, 2021 (IJEBAR)

E-ISSN: 2614-1280 P-ISSN 2622-4771

https://jurnal.stie-aas.ac.id/index.php/IJEBAR

non-governmental public institutions, where public institutions receive demands from the public to be managed in a transparent and responsible manner (Renyowijoyo, 2010).

According to Prof. Indra Bastian, Phd, Public sector accounting is an accounting technique and analysis mechanism that is applied to the management of public funds in high state institutions and departments under them, local governments, State-owned enterprises State and Regional Owned Enterprises, NGOs and social foundations, as well as on projects. public and private sector cooperation (Bastian, 2019).

According to Handayani (2019), public sector accounting is a system used by public institutions as a means of accountability to the public (Handayani, 2019). Public sector accounting is related to three main things, namely the provision of information, management control and accountability (Sari, 2016).

\section{Provision of Information}

Public sector accounting is a means of providing information for the government as well as an information tool for the public. For the government, accounting information is used in the management control process starting from strategic planning, programming, budgeting, performance evaluation, and performance reporting (Untary and Ardiyanto, 2015).

\section{Management Control System}

Public sector accounting is a process of management control, accounting is needed in making public sector financial reports in the form of surplus / foreign exchange reports on government. Accounting information as a management control tool is useful for decision making, to allocate resources and is also used to determine performance indications as a basis for performance appraisal (Astini, Sulindawati and Sinarwati, 2014).

Internal control system Government Regulation No. 60 of 2008 concerning the Government Internal Control System (SPIP) defines a government internal control system as an integral process of actions and activities carried out continuously by the leadership and all employees to provide adequate confidence in the achievement of organizational goals through effective and efficient activities, reliability of financial reporting, safeguarding state assets, and compliance with laws and regulations (Indonesia, 2008).

The village government can direct all its capabilities and expertise in effective internal control to be able to produce quality financial information reports as a form of good service to the community, in managing village funds according to PSAP No.1 (Elkha, 2020).

\section{Accounting Information Technology}

Information technology is a set of tools that help in working with information and performing tasks related to information processing (Abdul Karir, 2013). Information technology includes computers (mainframe, mini, micro), software, databases, networks (internet, intranet), electronic commerce, and other types related to technology (Rudianto, 2010).

\section{Apparatus Competence}

Competence is the work ability of each individual which includes aspects of knowledge, skills and work attitudes in accordance with established standards, is effective and efficient and is responsible to the organization (Nasfi, Rahmad, 2020). In Aruan (2003), Government 
International Journal of Economics, Business and Accounting Research (IJEBAR)

Peer Reviewed - International Journal

Vol-5, Issue-1, 2021 (IJEBAR)

E-ISSN: 2614-1280 P-ISSN 2622-4771

https://jurnal.stie-aas.ac.id/index.php/IJEBAR

apparatus competence means the abilities that an apparatus must have in the form of knowledge, skills, attitudes and behaviors needed in carrying out their duties (Inapty and Martiningsih, 2016).

\section{Accountability}

According to Mark Bovens et al (2014), accountability is the delivery of accounting and financial administration information that is fair, equitable and transparent to parties in need, including the public (Bovens, Schillemans and Goodin, 2014). The concept of accountability is a concept that must be implemented for both private and public entities (Küsters, Truderung and Vogt, 2010).

Public sector accountability is the obligation of the agent to provide accountability, present, report, disclose all activities that are under its responsibility to the principal who has the right and authority to hold it accountable (Renyowijoyo, 2018).

According to Wembi Banga (2017), there are four dimensions of accountability that must be met by public sector organizations, namely; 1) Accountability for legal honesty and accountability, 2) Process accountability, 3) Program accountability, 4) Policy accountability (Banga, 2017).

\section{Village Fund Management}

Village Fund according to Law no. 60 of 2014 is funds sourced from the APBN (State Revenue and Expenditure Budget) allocated for Villages which are transferred through the Regency / City APBD (Regional Revenue and Expenditure Budget) and used to finance governance, implementation of development, community development, and empowerment Public (Astuti and Yulianto, 2016).

The definition of "village fund management" is a process or a series of work carried out by a series of groups of people in which there is planning, organization, implementation and supervision by utilizing the existing potential in achieving certain goals, according to Presidential Regulation No.60 article 2, which reads Village Fund. managed in an orderly manner, obeying the provisions of laws and regulations, efficient, economical, transparent, and responsible with due regard for a sense of justice and propriety and prioritizing the interests of the local community (Sunardi and Lesmana, 2020).

\section{Nagari / Village Government}

According to Ahmad Kosasih in Gebu Minang (2011), defining Nagari/Village is the geographic area of Minangkabau, which is an association of at least four tribes, has clear boundaries, has separate governance in the sense of adat, and has ulayat nagari land (Kosasih, 2013).

According to Nasfi (2020), Nagari/Village is an area geographically and historically based on customs, which is led and promoted jointly by the community, clan leader (ninik mamak) lead traditionally and walinagari lead in government (Nasfi and Ariani, 2020).

\section{Previous Research}

Ibnu Wardana (2016), found that the presentation of financial reports, accessibility of financial reports, and internal control has a positive effect on the accountability of Village Fund 
International Journal of Economics, Business and Accounting Research (IJEBAR)

Peer Reviewed - International Journal

Vol-5, Issue-1, 2021 (IJEBAR)

E-ISSN: 2614-1280 P-ISSN 2622-4771

https://jurnal.stie-aas.ac.id/index.php/IJEBAR

management, quantitative research using the dependent variable is Village Fund Management Accountability, while the independent variables have in common, namely the Effect of the Internal Control System, The difference in this study using independent variables, namely the effect of the use of information technology and the ability of the Nagari / Village apparatus (Wardana, 2016).

Lalita Ivana Maria Ladapase (2019) Quantitative research with survey methods shows that the influence of Apparatus Competence, Apparatus Motivation, and Organizational Commitment has a positive effect on the Accountability of Village Fund Management, this research variable also has similarities in testing, namely the normality test, validity test, test Reliability, Multicollinearity Test, Heteroscedasticity Test, F Test, Coefficient of Determination $\left(\mathrm{R}_{2}\right)$ and $\mathrm{T}$ Test. Organizational Commitment, while in this study using independent variables, namely the influence of the internal recognition system and the use of Information Technology. Another difference is that Lalita Ivana Maria's research was conducted in Sikka Regency in 2019, while this research was conducted in Agam Regency in 2020 (Ladapase, 2019).

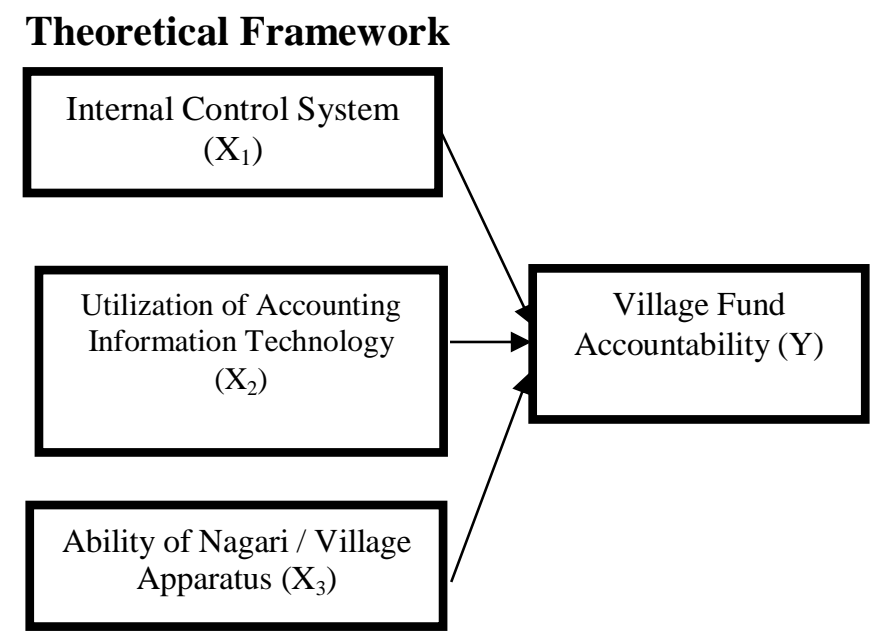

Figure 1 Theoretical Framework

From the chart above, it can be seen that there is a relationship between the Internal Control System, Utilization of Accounting Information Technology, the Ability of Nagari / Village Apparatus Accountability for Village Fund Management

\section{Hypothesis}

The hypothesis is a temporary answer to the formulation of the research problem, until it is proven through the collected data. The hypothesis that will be proposed in this study is

$H_{1:}$. There is a significant positive effect of the Internal Control System on the Accountability of Village Fund Management in Nagari/Village Government in Agam Regency.

$\mathrm{H}_{2}$ : There is a significant positive effect of the Utilization of Accounting Information Technology on the Accountability of Village Fund Management in Nagari / Village Governments in Agam Regency 
International Journal of Economics, Business and Accounting Research (IJEBAR)

Peer Reviewed - International Journal

Vol-5, Issue-1, 2021 (IJEBAR)

E-ISSN: 2614-1280 P-ISSN 2622-4771

https://jurnal.stie-aas.ac.id/index.php/IJEBAR

$H_{3}$ : There is a significant positive effect on the Ability of Nagari Apparatus on the Accountability of Village Fund Management in Nagari / Village Governments in Agam Regency.

\section{Research Method}

This type of research is quantitative, which is a process of finding knowledge using data in the form of numbers as a means of finding information about what you want to know (Suharsaputra, 2012). The research period was November 2019 to June 2020, where the Nagari / Village Administration was in Agam Regency. The research variable is an attribute or nature or value of the person, object or activity that has certain variations determined by the researcher to study and draw conclusions (Sugiyono, 2008). Research variables, the dependent variable is the variable that is affected or that is the result, because of the independent variables. Dependent variable (Y) in this research is Village Fund Management Accountability. Dependent variable (Bound) is Village Fund Management Accountability. The independent variable is a variable that has an influence or that affects or causes changes in the dependent variable. The independent variables $(\mathrm{X})$ in this study are: $\mathrm{X}_{1}$ : Internal Control System, $\mathrm{X}_{2}$ : Utilization of Accounting Information Technology and $\mathrm{X}_{3}$ : Capability of Nagari/Village Apparatus. Measurement of variables is described in a Likert scale.

Population can be defined as a set or set of elements, elements, or units within a certain area or scope, which has certain attributes or characteristics, and is determined by the researcher as the object of research analysis (Wahyudin, 2015), with 80 Nagari in Agam District, the sample is a data collection procedure in which only a part of the population is taken and used to determine the desired characteristics and characteristics of a population (Siregar, 2013), with the sampling technique in this study, namely convanience sampling. convanience sampling is the determination of the sample based on the ease of obtaining (Amirullah, 2015), with a sample of 20 villages

The data collection technique with this Likert scale uses five assessment points, namely (1) Strongly Disagree, (2) Disagree, (3) Disagree, (4) Agree, and (5) Strongly Agree (Sugiyono, 2008).

Data analysis techniques are the process of collecting, modeling and transforming data with the aim of sorting and obtaining useful information, providing suggestions, conclusions and supporting research decision making (Echdar, 2017), with Validity Test and Reliability Test. The validity test is used to measure whether a questionnaire is valid or not, validity means the extent to which the accuracy and accuracy of a measuring instrument (test) in performing its measuring function (Nasfi, Rahmad and Sabri, 2020). Testing the validity of the data is done by correlating the score between the questions and the total score of the variable, if $r_{\text {count }}>r_{\text {tabel }}$ then the questionnaire is declared valid and if $r_{\text {count }}<r_{\text {table }}$ then the questionnaire is said to be invalid (Rosniyenti, Sabri, 2020).

Reliability test is a measure of the stability and consistency of the respondent in answering matters relating to question constructs which are the dimensions of a variable and arranged in the form of a questionnaire. A questionnaire is said to be reliable or reliable if someone's answer to a question is consistent or stable over time (Rahmad, Sabri and Nasfi, 2020). Overall, all the variables in this study had Croanbach's alpha value above 0.60 . Thus, it can be interpreted that all variables are reliable or reliable. In other words, all question 
International Journal of Economics, Business and Accounting Research (IJEBAR)

Peer Reviewed - International Journal

Vol-5, Issue-1, 2021 (IJEBAR)

E-ISSN: 2614-1280 P-ISSN 2622-4771

https://jurnal.stie-aas.ac.id/index.php/IJEBAR

instruments used were stable and consistent in measuring each research variable. Before carrying out regression analysis, it is necessary to test the previous classical assumptions in the form of normality tests, multicollinearity and heteroscedasticity tests, this is done so that the sample data processed can represent the population as a whole (Umar, 2013).

\section{Results and Discussion}

\subsection{Results}

\section{Validity test}

The independent variable $(\mathrm{X})$ is obtained, namely, Internal Control System $\left(\mathrm{X}_{1}\right)$, Utilization of Accounting Information Technology $\left(\mathrm{X}_{2}\right)$, competence of the Nagari / Village apparatus $\left(\mathrm{X}_{3}\right)$, and the dependent variable $(\mathrm{Y})$, namely Village Fund Management Accountability. In this test it is known that $\mathrm{n}=70$ and a significant value of 0.5 , then the $\mathrm{r}$ table is obtained of 0.235 . Then the questionnaire can be declared valid if rcount is greater than rtable. The results of all rcount values are greater than the rtabel value, it can be concluded that all statements in the questionnaire are valid.

\section{Reliability Test,}

The indicator for reliability testing is Croanch Alpha, if the Croanbach Alpha value is> 0.6 then the instrument used is reliable and if the Croanbach Alpha $<0.6$ then the instrument used is not reliable. Primary data from the output of SPSS 16 are processed in 2020 results from Croanbach Alpha Internal Control System 0.751, Utilization of Accounting Information Technology 0.758, Nagari Apparatus Competence 0.768 and Village Fund Management Accountability 0.767 . The above results indicate that all variable reliability tests are $>0.6$ then these results declared reliable or consistent.

\section{Multicolinearity test}

Determining the multicolinearity test, decisions are made based on the VIF value, if VIF $<10.00$ then multicolinearity does not occur and if VIF> 10.00 then multicolinearity occurs. Multicolinearity test results from the primary data of the processed SPSS 16 output, that multicolinearity does not occur because the results of the VIF (VIF Internal Control System, Utilization of Information Technology, Nagari / Village Apparatus Competence) are small independent variable.

\section{Heteroscedasticity test}

The test in this test is carried out using the Glejser method, if the significant value $<0.05$ then heteroscedasticity occurs and if the significant value $>0.05$ then heteroscedasticity does not occur. The results of the primary data processing output of SPSS 16, that the Glejser test carried out a significant value for the internal control system variable of 0.210 , for the use of accounting information technology of 0.998 , for the competence of the village / village apparatus of 0.355 . All variables have a significant level greater than 0.05 , this means that there is no heteroscedasticity problem or the statistical data does not contain the classic assumption of heteroscedasticity. 
International Journal of Economics, Business and Accounting Research (IJEBAR)

Peer Reviewed - International Journal

Vol-5, Issue-1, 2021 (IJEBAR)

E-ISSN: 2614-1280 P-ISSN 2622-4771

https://jurnal.stie-aas.ac.id/index.php/IJEBAR

Hypothesis testing, multiple linear regression analysis was done using SPSS21, the following results were obtained:

Table 2

Multiple Linear Regression Analysis

Coefficients $^{\text {a }}$

\begin{tabular}{|l|r|r|r|r|r|}
\hline \multirow{2}{*}{ Model } & \multicolumn{2}{|c|}{$\begin{array}{c}\text { Unstandardized } \\
\text { Coefficients }\end{array}$} & $\begin{array}{l}\text { Standardized } \\
\text { Coefficients }\end{array}$ & \multicolumn{1}{c|}{$\mathrm{t}$} & \multicolumn{1}{c|}{ Sig. } \\
\cline { 2 - 6 } & \multicolumn{1}{c|}{$\mathrm{B}$} & Std. Error & \multicolumn{1}{c|}{ Beta } & & \\
\hline 1(Constant $)$ & 7.784 & 4.304 & & 1.809 & .075 \\
SPI $\left(\mathrm{X}_{1}\right)$ & .018 & .125 & .016 & .147 & .884 \\
PTIA $\left(\mathrm{X}_{2}\right)$ & .220 & .105 & .222 & 2.098 & .040 \\
KAN $\left(\mathrm{X}_{3}\right)$ & .584 & .101 & .609 & 5.790 & .000 \\
\hline
\end{tabular}

Source: Primary data from the output of SPSS16

Based on table 2 it is known that:

a. The first hypothesis, it is known that the Internal Control System variable $\left(\mathrm{X}_{1}\right)$ has a significant value of $0.884>0.05$ and a tcount value of $0.147<\mathrm{t}_{\text {table }} 1.9998$, it can be concluded that the Internal Control System has no influence on the Village Fund Management Accountability, this means that it is getting higher or the lower the Internal Control System will not increase the Village Fund Management Accountability with an error rate of 5\%.

b. The second hypothesis, it is known that the Accounting Information Technology Utilization variable $\left(\mathrm{X}_{2}\right)$ has a significant value of $0.04<0.05$ and has a tcount of more than 2.098> 1.998 so it can be concluded that the Use of Accounting Information Technology has an influence on the Accountability of Village Fund Management, this is means that the higher the Utilization of Accounting Information Technology, the greater the Accountability of Village Fund Management with an error rate of $5 \%$.

c. The third hypothesis is known that the Nagari / Village Apparatus Competency variable $\left(\mathrm{X}_{2}\right)$ has a significant value of $0.00<0.05$ and has a value of tcount more than 5.790 $>\mathrm{t}$ table 1.998 , so it can be concluded that Nagari Apparatus Competence has an influence on the Accountability of Village Fund Management, this is means that the higher the competency of the Nagari apparatus, the more the Accountability of Village Fund Management with an error rate of $5 \%$.

\subsection{Discussion}

From the results of data analysis carried out in this study, it can be seen that the independent variables of the Internal Control System $\left(\mathrm{X}_{1}\right)$, the Utilization of Accounting Information Technology $\left(\mathrm{X}_{2}\right)$, the Competence of Nagari Apparatus $\left(\mathrm{X}_{3}\right)$ jointly affect the dependent variable (Y) Accountability of Village Fund Management. In separate testing carried out with the $t$ test, the results of hypothesis testing can be seen as follows: 
International Journal of Economics, Business and Accounting Research (IJEBAR)

Peer Reviewed - International Journal

Vol-5, Issue-1, 2021 (IJEBAR)

E-ISSN: 2614-1280 P-ISSN 2622-4771

https://jurnal.stie-aas.ac.id/index.php/IJEBAR

\section{1) The Effect of Internal Control Systems on the Accountability of Village Fund Management.}

Based on the $t$ test for the first hypothesis, namely the Internal Control System variable, the results of the t-count value of 0.14 are smaller than the t table which is 1.9998 . Thus it can be interpreted that the Internal Control System has no influence on the Village Fund Management Accountability.

The results of this study are in line with research conducted by Eli Budi Santoso in 2016 which said that the Internal Control System did not have a significant effect on the Accountability of Village Fund Management so that the increase in the Internal Control System in Village Government did not necessarily increase the Accountability of Village Fund Management.

Internal Control System is a control that is carried out so that an organization's goals are achieved effectively and efficiently and reliability in financial reporting in order to minimize fraud (Wardana, 2016). In the research conducted, it was found that the Internal Control System did not significantly influence the Accountability of Village Fund Management, this was because in the Village Fund Management the Nagari Government had exercised control guided by the Village Law and Government Regulations regarding Villages. Judging from budget preparation, budget implementation, and accountability reporting for Village Fund management in the form of Nagari Government financial reports have been guided by Permendagri Number 113 of 2014 concerning Village Fund Management, in addition to referring to that, accountability reporting in the form of financial reports on the management of Village Funds for the Nagari Government is also based on to PSAP No. 71 concerning Government Accounting standards, in the management of Village Funds in addition to Regulations from the Central Government of Agam Regency, it also provides Regional Regulations as controls to achieve accountability in the implementation of Nagari finances, namely Agam Regent Regulation No. 50 of 2018 concerning Guidelines for Nagari Financial Management.

So that the Nagari Government uses the laws and regulations from the Central and Regional Governments as controls in achieving Accountability for Village Fund Management.

\section{2) The Effect of Using Accounting Information Technology.}

Based on the $t$ test for the second hypothesis, namely the variable Utilization of Accounting Information Technology, the result is that the tcount value of 2.098 is greater than the $t$ table which is 1.9998 . Thus it can be interpreted that the Use of Accounting Information Technology affects the Accountability of Village Fund Management. This is in line with research conducted by Meitri Yani Herlinse in 2018 saying that the Use of Accounting Information Technology affects the Accountability of Village Fund Management, if accounting information technology in the Nagari government is maximally utilized in helping the management of Village Funds, the accountability of Village Fund management will increase.

Obligations in the use of information technology by the central and local governments as stipulated in PP. 56 of 2005 concerning the Regional financial system which is expected to develop and take advantage of advances in accounting information technology to improve 
International Journal of Economics, Business and Accounting Research (IJEBAR)

Peer Reviewed - International Journal

Vol-5, Issue-1, 2021 (IJEBAR)

E-ISSN: 2614-1280 P-ISSN 2622-4771

https://jurnal.stie-aas.ac.id/index.php/IJEBAR

regional financial management capabilities, and channel regional financial information to public services which is one form of accountability in village financial management.

\section{3) The Influence of Nagari / Village Apparatus Competencies}

Based on the $t$ test for the third hypothesis, namely the Nagari Apparatus Competency variable, the results of the t-count value of 5.790 are greater than the t-table which is 1.9998 . Thus it can be interpreted that the competence of the Nagari apparatus affects the Accountability of Village Fund Management. This is in line with research conducted by Lalita Ivana Maria Ladapase in 2019 which states that the competence of Village officials affects the accountability of Village Fund Management.

Apparatus competence is urgently needed in managing village finances, managing the Village Fund, starting from planning, implementation, reporting and accountability, must have competent apparatus in the field of financial management. With Nagari apparatus who understand the management of village finances, accountability can be achieved.

For this reason, the competence of Nagari officials is very much needed in the management of the Village Fund in order to achieve predetermined goals. To improve the competence of Nagari officials, the Nagari government can carry out BIMTEK, training, counseling and socialization about the management of Village Funds for Nagarai officials, especially for Village financial managers regarding the Village financial system so that officials understand more about Village Fund management.

\section{Conclusion}

Based on the research results it can be concluded as follows:

1) Based on the results of data analysis of the Internal Control System variable, it is found that the t-count value of 0.14 is smaller than the $t$ table, which is 1.9998 . Thus it can be interpreted that the Internal Control System has no influence on the Village Fund Management Accountability. This is because in the Village Fund Management the Nagari Government has carried out control and supervision based on the Village Law, Government Regulations concerning Villages and also the Village Fund pocket book.

2) Based on the second t test, namely the variable Utilization of Information Technology in Accounting, the results of the tcount value are 2.098, which is greater than the table, which is 1.9998 Thus it can be interpreted that the Use of Accounting Information Technology affects the Accountability of Village Fund Management. So the use of accounting information technology in Kenagarian can increase accountability in managing village funds.

3) Based on the third t test, namely the Nagari Apparatus Competency variable, the results of the tcount value of 5.790 are greater than the $t$ table, which is 1.9998 . Thus it can be interpreted that the competence of the Nagari apparatus affects the Accountability of Village Fund Management. So with competent apparatus in managing Village Funds, accountability for Village Fund Management can be achieved. 
International Journal of Economics, Business and Accounting Research (IJEBAR)

Peer Reviewed - International Journal

Vol-5, IsSue-1, 2021 (IJEBAR)

E-ISSN: 2614-1280 P-ISSN 2622-4771

https://jurnal.stie-aas.ac.id/index.php/IJEBAR

\section{Reference}

Abdul Karir, T. (2013) Pengantar Teknologi Informasi. Yogyakarta: Andi.

Amirullah, S. M. (2015) 'Metode Penelitian Manajemen'. Malang: Bayumedia Publishing Malang.

Astini, N. K., Sulindawati, N. L. G. E. and Sinarwati, N. K. (2014) 'Pengaruh Akuntabilitas Publik, Kejelasan Sasaran Anggaran, dan Sistem Pengendalian Manajemen Terhadap Kinerja Manajerial SKPD Di Kabupaten Klungkung', JIMAT (Jurnal Ilmiah Mahasiswa Akuntansi) Undiksha, 2(1).

Astuti, T. P. and Yulianto, Y. (2016) 'Good Governance Pengelolaan Keuangan Desa Menyongsong Berlakunya Undang-Undang No. 6 Tahun 2014', Berkala Akuntansi dan Keuangan Indonesia, 1(1).

Banga, W. (2017) 'Administrasi Keuangan Negara dan Daerah', Ghalia Indonesia, Bogor.

Bastian, I. (2019) Lingkup Akuntansi Sektor Publik. Universitas Terbuka.

Bovens, M., Schillemans, T. and Goodin, R. E. (2014) 'Public accountability', The Oxford handbook of public accountability. Oxford University Press Oxford, 1(1), pp. 1-22.

Echdar, S. (2017) 'Metode Penelitian Manajemen dan Bisnis', Bogor: Ghalia Indonesia.

Elkha, F. (2020) 'Pengaruh Pengendalian Internal, Akuntabilitas, dan Transparansi Pengelolaan Keuangan Daerh Terhadap Kinerja Pemerintah Daerah', Jurnal Ilmu dan Riset Akuntansi (JIRA), 9(3).

Febriyanti, S. and Halmawati, H. (2020) 'Analisis Efektivitas Dan Efisiensi Pengelolaan Dana Nagari (Studi Pada Nagari Di Kabupaten Agam)', JURNAL EKSPLORASI AKUNTANSI, 2(1), pp. 2331-2347.

Hamzah, R. Y. \& A. (2016) Konsep \& Aplikasi Akuntansi pemerintahan berbasis Akrual. Surabaya: Pustaka.

Handayani, M. (2019) Akuntansi Sektor Publik: Dilengkapi 100 Soal Latihan Dan Jawaban. POLIBAN PRESS.

Herdiyana, D. (2019) 'Analysis Of The Use Of Accouting Base On Village Government Entites', Jurnal JOBS, 5(2).

Inapty, M. A. F. B. A. and Martiningsih, R. R. S. P. (2016) 'Pengaruh penerapan standar akuntansi pemerintah, kompetensi aparatur dan peran audit internal terhadap kualitas informasi laporan keuangan dengan sistem pengendalian intern sebagai variabel moderating (Studi empiris pada SKPD di Pemprov NTB)', Akuntabilitas, 9(1).

Indonesia, R. (2008) 'Peraturan Pemerintah Nomor 60 Tahun 2008 tentang', Sistem Pengendalian Intern Pemerintah.

Indrawati, S. M. (2017) Buku Saku Dana Desa. Jakarta: Kementrian Keuangan.

Ismail, M., Widagdo, A. K. and Widodo, A. (2016) 'Sistem akuntansi pengelolaan dana desa', Jurnal Ekonomi dan Bisnis, 19(2), pp. 323-340.

Kosasih, A. (2013) 'Upaya penerapan nilai-nilai adat dan syarak dalam penyelenggaraan pemerintahan nagari', Humanus, 12(2), pp. 107-119.

Küsters, R., Truderung, T. and Vogt, A. (2010) 'Accountability: definition and relationship to verifiability', in Proceedings of the 17th ACM conference on Computer and communications security, pp. 526-535.

Ladapase, L. I. M. (2019) 'Pengaruh Kompetensi Aparatur, Motivasi Aparatur Dan Komitmen Organisasi Terhadap Akuntabilitas Pengelolaan Dana Desa Di Kecamatan Nelle, 
International Journal of Economics, Business and Accounting Research (IJEBAR)

Peer Reviewed - International Journal

Vol-5, Issue-1, 2021 (IJEBAR)

E-ISSN: 2614-1280 P-ISSN 2622-4771

https://jurnal.stie-aas.ac.id/index.php/IJEBAR

Kecamatan Koting Dan Kecamatan Kangae Kbupaten Sikka', Skripsi. Program Studi Akuntansi Fakultas Ekonomi Universitas Sanata Dharma Yogyakarta.

Lumempow, F., Elim, I. and Suwetja, I. G. (2017) 'Evaluasi Kinerja Pengawasan Pengelolaan Keuangan Daerah dari Peraturan BPKP N0. 16 Tahun 2015 Pada Inspektorat Kabupaten Minahasa Selatan', GOING CONCERN: JURNAL RISET AKUNTANSI, 12(2).

Nasfi, Rahmad, S. (2020) 'Pengaruh Diklat Kepemimpinan Dan Pengembangan Karir Terhadap Kinerja Pegawai Dinas Koperasi UMKM Provinsi Sumatera Barat', Al-Fikrah: Jurnal Manajemen Pendidikan, 8(1), pp. 11-28. doi: http://dx.doi.org/10.31958/jaf.v8i1.2025.

Nasfi, N. (2020) 'Pengembangan Ekonomi Pedesaan Dalam Rangka Mengentas Kemiskinan di Pedesaan', Jurnal EL-RIYASAH, 11(1), pp. 54-66. doi: http://dx.doi.org/10.24014/jel.v11i1.8818.

Nasfi, N. and Ariani, D. (2020) 'Komunikasi Persuasif Pemerintah Nagari Sungai Pua Kepada Ninik Mamak Untuk Mencapai Pembangunan Sosial dan Ekonomi', JUSIE (Jurnal Sosial dan Ilmu Ekonomi), 5(01), pp. 122-135. doi: https://doi.org/10.36665/jusie.v5i01.

Nasfi, N., Rahmad, R. and Sabri, S. (2020) 'Pengaruh Kualitas Pelayanan Terhadap Kepuasan Nasabah Perbankan Syariah', Ekonomika Syariah: Journal of Economic Studies, 4(1), pp. 19-38. doi: 10.30983/es.v4i1.3146.

Pahlawan, E. W., Wijayanti, A. and Suhendro, S. (2020) 'Pengaruh kompetensi aparatur desa, sistem pengendalian internal, pemanfaatan teknologi informasi dan partisipasi masyarakat terhadap akuntabilitas pengelolaan dana desa', Indonesia Accounting Journal, 2(2), pp. 162-172.

Rahmad, Sabri and Nasfi, N. (2020) 'Pengaruh Faktor Pribadi, Organiasi dan Non Organisasi Terhadap Komitmen Organisasi Karyawan Pada PT. PLN Area Bukittinggi', Jurnal Apresiasi Ekonomi, 8(1), pp. 142-152. doi: https://doi.org/10.31846/jae.v8i1.

Renyowijoyo, H. M. (2018) Akuntansi Sektor Publik organisasi non laba. Mitra Wacana Media.

Renyowijoyo, M. (2010) 'Akuntansi Sektor Publik Organisasi Non Laba Edisi Kedua', Penerbit Mitra Wacana Media. Yogjakarta.

Rosniyenti, Sabri, N. (2020) 'Analisis Pengaruh Merek, Harga, dan Produk Terhadap Kepuasan Pelanggan Levi's Tailor Simpang Senggol Biaro Kab. Agam', Jurnal Ekonomi, 23(2), pp. 97-116. doi: https://doi.org/10.47896/je.v23i2.182.

Rudianto (2010) Akuntansi Koperasi. kedua. Jakarta: Erlangga.

Rustiarini, N. W. and Denpasar, U. M. (2016) 'Good Governance dalam Pengelolaan Dana Desa', Simposium Nasional Akuntansi, pp. 1-18.

Sabri, S. et al. (2019) 'Prosedur Pencairan dan Penerimaan Alokasi Dana Desa (ADD) untuk Pembangunan Nagari Tabek Panjang Kecamatan Baso Kabupaten Agam', JUSIE (Jurnal Sosial dan Ilmu Ekonomi), 4(02), pp. 129-142. doi: https://doi.org/10.36665/jusie.v4i02.

Sari, R. M. (2016) 'Rencana Anggaran Keuangan Daerah Basis Konsep Peran Akuntansi Sektor Publik (Studi Pada Pemda Kabupaten Tulungagung)', Jurnal Kompilasi Ilmu Ekonomi (KOMPILEK), 8(1), pp. 1-7.

Sari, Y. (2017) 'Akuntabilitas Pengelolaan Keuangan Nagari di Nagari Cubadak Kecamatan Lima Kaum Kabupaten Tanah Datar Tahun 2016', Jurnal Administrasi dan Kebijakan Publik, 2(3), pp. 241-254.

Siregar, S. (2013) 'Metode penelitian kuantitatif', Jakarta: kencana.

Sugiyono, D. (2008) 'Metode penelitian bisnis', Bandung: Pusat Bahasa Depdiknas. 
International Journal of Economics, Business and Accounting Research (IJEBAR)

Peer Reviewed - International Journal

Vol-5, Issue-1, 2021 (IJEBAR)

E-ISSN: 2614-1280 P-ISSN 2622-4771

https://jurnal.stie-aas.ac.id/index.php/IJEBAR

Suharsaputra, U. (2012) 'Metode penelitian kuantitatif, kualitatif, dan tindakan', Bandung: Refika Aditama.

Sunardi, N. and Lesmana, R. (2020) 'Pelaksanaan Alokasi Dana Desa Terhadap Manajemen Keuangan Desa dalam Meningkatkan Efektivitas Program Desa Sejahtera Mandiri Di Desa Cihambulu, Kec. Pabuaran, Kab. Subang', Jurnal SEKURITAS (Saham, Ekonomi, Keuangan dan Investasi), 3(3), pp. 277-288.

Umar, H. (2013) 'Metode Penelitian Skripsi dan Tesis Bisnis (Edisi 2)', Jakarta: Rajawali Pres.

Untary, N. R. and Ardiyanto, M. D. (2015) 'Pengaruh sistem informasi akuntansi, sistem pengendalian intern dan kompetensi sumber daya manusia terhadap kualitas laporan keuangan Daerah dengan faktor eksternal sebagai pemoderasi (studi kasus pada Pemerintah Daerah Kabupaten Magelang)'. Fakultas Ekonomika dan Bisnis.

Wahyudin, Z. (2015) 'Penelitian Pendidikan Matematika'. Bandung: PT Refika Aditama.

Wardana, I. (2016) 'Akuntabilitas dalam pengelolaan keuangan desa (studi pada pemerintah desa di Kabupaten Magelang)'. Universitas Negeri Semarang.

Widyatama, A., Novita, L. and Diarespati, D. (2017) 'Pengaruh Kompetensi dan Sistem Pengendalian Internal Terhadap Akuntabilitas Pemerintah Desa dalam Mengelola Alokasi Dana Desa (ADD)', Berkala Akuntansi dan Keuangan Indonesia, 2(2). 